\title{
TALENT MANAGEMENT AND THE JOURNEY TOWARDS GENDER EQUALITY AND WOMEN'S EMPOWERMENT IN SOUTH KOREA
}

\begin{abstract}
Esin Yurdagul
Lack of gender equality affects talent management. The journey towards gender equality can be achieved through diversity, inclusion, and empowerment which is a continuous process, according to the International Labour Organization. This paper examines the importance and significance of achieving gender equality in South Korea through diversity, inclusion, and empowerment in public as well as private sector organisations which are shaped by a strict form of Confucianism. The impact of this on talent management in the country is then assessed.
\end{abstract}

Keywords: South Korea, Talent Management, Government and Private Sector Organisations, Gender Equality

\section{WHAT IS TALENT?}

The definition of talent has evolved from the biblical times when it was used to refer to a very large sum of money while in present times it means cognitive ability. ${ }^{1}$ The term was first utilised in business literature in the 1970s in the context between human resource development and organisational effectiveness ${ }^{2}$ while the term Talent Waste was used to describe the extent to which institutions of learning misdirected or misused human resources. ${ }^{3}$ These days, talent has become a popular term among academicians and practitioners especially over the last two decades. ${ }^{4}$

\section{WHAT IS TALENT MANAGEMENT?}

The term talent management (TM) was first used in a document published by the American Management Association in $1957^{5}$ which defined it 'as the anticipation of required human capital for an organisation and the planning to meet those needs'. ${ }^{6}$ Heathfield highlighted it as a business strategy that organisations use to enable them to retain their topmost talented and skilled employees. ${ }^{7}$ Talent management is the science of using strategic human resource

\footnotetext{
${ }^{1}$ Ansar, N., \& Baloch, A., 'Talent and talent management: Definition and issues,' IBT Journal of Business Studies Volume, 14(2), pp: 213-230, 2018.

${ }^{2}$ https://encyclopedia.thefreedictionary.com/talent+management; Schein, E., 'Increasing organizational effectiveness through better human resources planning and development,' Sloan Management Review, Vol. 19(1), p. 01, 1997.

${ }^{3}$ Ritterbush, P.C., Talent waste: How institutions of learning misdirect human resources, Acropolis Books, 1972.

${ }^{4}$ Ansar, N., \& Baloch, A., 'Talent and talent management: Definition and issues,' IBT Journal of Business Studies Volume, 14(2), pp: 213-230, 2018.

${ }^{5}$ Ansar, N., \& Baloch, A., 'Talent and talent management: Definition and issues,' IBT Journal of Business Studies Volume, 14(2), pp: 213-230, 2018; Dooher, M. J., \& Marting, E., 'Selection of management personnel, Volume 1,' American Management Association, 1957.

${ }^{6}$ Carpenter, M., Bauer, T., \& Erdogan, B., 'Management and organizational behavior (Version 1.1.1),' Flatworld Knowledge, Vol. 409, 2013.

${ }^{7}$ Heathfield, S.M., 'Why talent management is an important business strategy to develop,' Thebalancecareers, 2019.
} 
planning in order to increase the value of business. In other words this allows to lead companies and organisations to accomplish their goals and resolutions. ${ }^{8}$ Talent management is regarded as an established field with growing importance, yet one might still frequently witness the evolution of the definition and boundaries of talent management ${ }^{9}$ and there is no consensus of its objective definition. ${ }^{10}$ For the purpose of this paper, talent management refers to talent acquisition (and recruitment), learning and development, organisational values and vision, performance management, career pathways, and succession planning. There are many talent management models, but in general, TM covers the following: planning, attracting, developing, retaining, and transitioning. ${ }^{11}$ It overlaps with human resource management in the areas of competence management, human resource planning, succession management, and human capital. ${ }^{12}$ The notable practices of TM are developing strategy; identifying talent gaps; succession planning; and recruiting, selecting, educating, motivating and retaining talented employees through a variety of initiatives. ${ }^{13}$

\section{TRAJECTORY OF TALENT MANAGEMENT}

The notion of talent management can be traced to the Second World War. ${ }^{14}$ In the 1970 s and 1980s, the personnel department was responsible for recruitment, namely to hire people, offer appropriate, salary, and offer other employment benefits. Batch payroll systems were used to support this function. The personnel department was thought of as a well-understood business function. In the 1980s and 1990s, organisations actually comprehended the importance and significance of Human Resource function. As a result, the concept of Strategic Human Resource begun to become more apparent. During this period, organisations were cognizant of the fact that the Vice President of Human Resource had a much larger role which was to recruit the right people, train them, help the business design job roles and provide organisational structures (organisational design), develop total compensation packages that include benefits, stock options and bonuses, and serve as a central point of communication to ensure employee well-being.

The Head of Personnel was always the Vice President of Human Resource and he or she has a very important role in business strategy and execution. The systems to support this new role were recruitment and applicant tracking system, portals, total compensation systems, and learning management systems. In this role, the Human Resource Department was a business partner who reaches out to support the line of business. ${ }^{15}$ Talent management represents one of the fastest growing areas of not only academic research but also human resource development practice. Since the mid-1990s, talent management has become a management practice and discourse with minimal critique from not only practitioners but also

\footnotetext{
${ }^{8}$ https://encyclopedia.thefreedictionary.com/talent+management

${ }^{9}$ Galarza, D., \& Wickenberg, J., 'The mechanistic and political frames of talent management processes: The case of a talent analytics system,' Chalmers University of Technology, 2011.

${ }^{10}$ Ansar, N., \& Baloch, A., 'Talent and talent management: Definition and issues,' IBT Journal of Business Studies Volume, 14(2), pp: 213-230, 2018.

${ }^{11}$ Momtazian, M., 'What is talent management and why is it important?' Expert360, 2020.

${ }^{12}$ Galarza, D., \& Wickenberg, J., 'The mechanistic and political frames of talent management processes: The case of a talent analytics system,' Chalmers University of Technology, 2011.

${ }^{13}$ Groves, K.S., 'Integrating leadership development and succession planning best practices,' Journal of Management Development, Vol. 26(3), pp: 239-260, 2005; Guthridge, M., \& Komm, A.B., 'Why multinationals struggle to manage talent,' The McKinsey Quarterly, pp. 01-05, 2008; Ringo, T., Schweyer, A., DeMarco, M., Jones, R., \& Lesser, E., 'Integrated talent management-Turning talent management into a competitive advantageAn industry view,' IBM Global Business Services, 2010.

${ }^{14}$ Cappelli, P., Talent on demand: Managing talent in an age of uncertainty, Harvard Business School Press, 2008.

${ }^{15}$ Bersin, J., 'Talent management What is it? Why now?' Hay Acquisition Company, 2006.
} 
academics; there is limited empirical studies on talent management outcomes. ${ }^{16}$ In particular, it emerged as one of the most common terms in the managerial and Human Resource Development practitioner lexicon. ${ }^{17}$ Later multinational corporations realized that there was a shortage of talent. ${ }^{18}$ Not surprisingly many organizations began to seek for better talents in the work force. ${ }^{19}$

\section{RESEARCH ON TALENT MANAGEMENT}

Some studies have that suggested a positive correlation between companies with more women in senior leadership and in boards of directors produce better financial performance. Therefore, due to improved performance of firms having better gender diversity, more innovative policies in business environment are important. It has been documented that firms which have at least two women managers have minimised talent loss and in fact gained increased market shares and benefits. ${ }^{20}$ Poor talent management practices can have disastrous effects in organisations that have more employees than needed leading to lay-offs, shortages of qualified people in critical areas, or an adverse impact in operations when key resources leave the company. ${ }^{21}$ In contrast gender-diverse workforce created by an effective talent management improves business performance. Women's different perspectives contribute to "gender-diverse teams than homogeneous ones across the large number of different tasks. "22 Those organisations that are committed to achieve gender equality in their talent management practices are apparently,

...more disciplined with their commercial emphasis, their accountability mechanisms, their governance processes, and their selection for higher-level appointments, their leadership development and sponsorship. They are innovative and use systems change methods, and are anything but complacent. Their advice is clear: embed and blend gender inclusion into the business, creating people and client synergies. ${ }^{23}$

\footnotetext{
${ }^{16}$ Sheehan, M., \& Anderson, V., 'Talent management and organizational diversity: A call for research,' Human Resource Development Quarterly, Vol. 26(4), 2015.

${ }^{17}$ Minbaeva, D., \& Collings, D.G., 'Seven myths of global talent management,' International Journal of Human Resource Management, Vol. 24(9), pp: 1762-1776, 2013; Sheehan, M., \& Anderson, V., 'Talent management and organizational diversity: A call for research,' Human Resource Development Quarterly, Vol. 26(4), 2015.

${ }^{18}$ Scullion, H., \& Collings, D.G., 'Global talent management,' Journal of World Business, Vol. 45, pp: 105-108, 2010; Ma“kela“, K., Bjo“rkman, I., \& Ehrnrooth, M., 'How do MNCs establish their talent pools? Influences on individuals' likelihood of being labeled as talent,' Journal of World Business, Vol. 45, pp: 134-142, 2010.

${ }^{19}$ Chambers, E., Foulon, M., Handfield-Jones, H., Hankin, S., \& Michaels III, E., 'The war for talent,' The McKinsey Quarterly, Vol. 3, pp: 44-57, 1998; Michaels, E., Handfield-Jones, H., \& Axelrod, B., The war for talent, Harvard Business Press, 2001; Bersin, J., 'Talent management What is it? Why now?' Hay Acquisition Company, 2006.

${ }^{20}$ Catalyst, 'The bottom line: Connecting corporate performance and gender diversity,' Catalyst, 2004; Catalyst, 'The bottom line: Corporate performance and women's representation on boards,' Catalyst, 2007; Catalyst, 'The bottom line: Corporate performance and women's representation on Boards (2004-2008),' Catalyst, 2011a; Catalyst, 'Gender and corporate social responsibility: It's a matter of sustainability,' Catalyst, 2011b; Renshaw, J.R., \& Lee, Joo-hee, 'Korea's unrecognized corporate scandal: The absence of women managers,' Japan Policy Research Institute Working Paper, Vol. 104, 2005.

${ }^{21}$ Cappelli, P., Talent on demand: Managing talent in an age of uncertainty, Harvard Business School Press, 2008; Galarza, D., \& Wickenberg, J., 'The mechanistic and political frames of talent management processes: The case of a talent analytics system,' Chalmers University of Technology, 2011.

${ }^{22}$ Woolley, A., Chabris, C., Pentland, A., Hashmi, N., \& Malone, T., 'Evidence for a collective intelligence factor in the performance of human groups,' Science, Vol. 330(2004), pp: 686-688, 2010.

${ }^{23}$ Jacobs, D., 'Women in the pipeline: Next practice actions, The Organization, November/December 2010,' Iveybusinessjournal, 2010.
} 
In addition, a similar correlation shows that the more women board directors exists in a company, the higher level of philanthropic decisions can be seen within the organization. ${ }^{24} \mathrm{At}$ the same time, if there are three or more women on company board, within a mere five years more women will occupy senior leadership. ${ }^{25}$ The Project Management Institute highlights that talent management explores the link between alignment of talent management strategy to project management performance and organizational success. ${ }^{26}$

Research suggests that gender diversity in business leadership and management teams produces better business outcomes, and decision-making is enhanced. ${ }^{27}$ Therefore, not surprisingly, attracting, developing and retaining talented workforce which promotes gender equality, is now being followed by gender-responsive talent management teams. ${ }^{28}$ Generally, research on talent management has accelerated, for instance, an Internet search results on talent management produced 749000.000 million datasets in $2021^{29}$ in comparison to 2700.000 in $2004{ }^{30}$ and 5750.000 in $2007 . .^{31}$

\section{TALENT MANAGEMENT IN SOUTH KOREA}

Talent management practices in South Korea are hierarchical and class-based society with both public and private sector organisations alike influenced by political power. This culture has led to the rise of very powerful family-owned corporate conglomerates with authoritarian management and centralised decision-making styles. ${ }^{32}$ The sexual discrimination legislation, also known as the Equal Employment Act of 1987, was adopted by the South Korean government to encourage gender diversity in workplace. The enforcement power of existing institutions, which includes the Ministry of Gender Equality's Committee on Gender Equality Promotion and the Ministry of Labour's Equal Employment Committee, has been very limited. Despite National Human Rights Commission of Korea having greater enforcement power, it lacks expertise in workplace dispute resolution. Additionally, its evaluation criteria

\footnotetext{
${ }^{24}$ Catalyst, 'Gender and corporate social responsibility: It's a matter of sustainability,' Catalyst, $2011 \mathrm{~b}$.

${ }^{25}$ Catalyst, 'The bottom line: Corporate performance and women's representation on Boards (2004-2008),' Catalyst, 2011a.

${ }^{26}$ Project Management Institute, 'The competitive advantage of effective organizational talent management,' Project Management Institute, 2013.

${ }^{27}$ International Labor Office (ILO), Gender diversity journey company good practices, Bureau for Employers' Activities (ACT/EMP): ILO Press, 2017; Ernst \& Young, 'Women, the next emerging market,' Ernst \& Young, Vol. 8, 2013; PricewaterhouseCoopers, 'Winning the fight for female talent: How to gain the diversity edge through inclusive recruitment,' PricewaterhouseCoopers, 2017.

${ }^{28}$ Milikić, B.B., 'Promoting gender-responsive talent management in police organizations through strategic HRM measuring,' Strategic Management, Vol. 24(1), pp: 19-29, 2019.

${ }^{29}$ Google, 'Talent management (About 749.000.000 Results),' Google, February 032021.

${ }^{30}$ Felix, C., \& Manuel, J., 'Talent management through the management fashion lens,' 2016. Ansar, N., \& Baloch, A., 'Talent and talent management: Definition and issues,' IBT Journal of Business Studies Volume, 14(2), pp: 213-230, 2018.

${ }^{31}$ Christensen-Hughes, J., \& Rog, E., 'Talent Management: A strategy for improving employee recruitment, retention and engagement within hospitality organizations,' International Journal of Contemporary Hospitality Management, Vol. 20(7), pp: 743-757, 2008. Ansar, N., \& Baloch, A., 'Talent and talent management: Definition and issues,' IBT Journal of Business Studies Volume, 14(2), pp: 213-230, 2018; Ahern, K.R., \& Dittmar, A.K., 'The changing of the boards: The impact on firm valuation of mandated female board representation,' Working paper, 2011.

${ }^{32}$ Though Korea saw rapid economic growth over a 20-year period; however, it led to a class-based approach to talent management, particularly among second-generation South Koreans who were born in the 1960s, and went to college in the 1980s. They entered senior executive positions and became politically active in the early 2000 s. Although their parents were born in the 1930s accepted an authoritarian style of government, their children experienced relative affluence who were aware of democratic rights and justice; Thornton III, G.C., Rupp, D.E., \& Hoffman, B.J., Assessment center perspectives for talent management strategies, Routledge, (2 ${ }^{\text {nd }}$ Eds.), 2015.
} 
Vol. 9, No. 1, 2020. pp. 61-74.

doi.org/10.22452/IJEAS.vol9no1.5

had a disparate impact on women workers whereby employers' that are subjected to personnel decisions cannot not be prevented by anti-discrimination laws. For that reason, the government introduced an employment equity promotion programme that was similar to the United States federal contract compliance programme, which required employers to submit detailed reports on employment patterns and explicit plans to remedy inequality.

The employers have to behave in good faith by presenting complete relevant personnel records and information. Interestingly, the legislation was not supported by women's groups. Some groups, which included the Korea Women's Association United and the Korean National Counsel of Women, wanted a quota system to be introduced in government and the public sector. However, these groups did not demand the government introduce a contract compliance programme to compel government contractors in the private sector to show their hiring goals and schedules for South Korean women workers. Women's groups including Women Workers Association believed that it was less urgent to introduce affirmative action that they felt would primarily benefit relatively well-educated middle class women. To them improving the wages and working conditions of non-standard women workers was more essential. $^{33}$

Table 1: Employment by occupation and sex (percentage) ${ }^{34}$

\begin{tabular}{|l|c|c|c|c|c|c|}
\hline & \multicolumn{2}{|c|}{ Male } & \multicolumn{2}{c|}{ Female } & \multicolumn{2}{c|}{ Total } \\
\hline Occupation & 1983 & 1990 & 1983 & 1990 & 1983 & 1990 \\
\hline Professional and Managerial & 7.3 & 9.6 & 4.1 & 8.4 & 6.1 & 9.1 \\
\hline Clerical & 11.3 & 14.6 & 9.2 & 13.9 & 10.5 & 14 \\
\hline Sales & 13.4 & 13.7 & 18.7 & 18.8 & 15.5 & 15.6 \\
\hline Service & 6.6 & 7.7 & 15.4 & 18.6 & 10.1 & 12 \\
\hline Agriculture and Fishery & 27.5 & 14.1 & 32.5 & 12.5 & 29.4 & 13.5 \\
\hline Manufacturing and Transportation & 33.8 & 40.8 & 20.1 & 27.8 & 28.9 & 35.8 \\
\hline
\end{tabular}

Source: (Chang 1994)

Since the emphasis on equal employment opportunities for women in the 1990s, discrimination against women was reduced to some extent, probably more due to a severe labour shortage in that decade. For instance, the government prosecuted private sector organisations that only wanted to recruit male applicants to particular positions. ${ }^{35}$ This led to corporations and non-business organisations finally recruiting even married women into the workforce. This was also a turning point in human resource management practices in South Korea. ${ }^{36}$ Previously South Korean women faced many obstacles due to the male-dominated

\footnotetext{
${ }^{33}$ Renshaw, J.R., \& Lee, Joo-hee, 'Korea's unrecognized corporate scandal: The absence of women managers,' Japan Policy Research Institute Working Paper, Vol. 104, 2005.

${ }^{34}$ The Economic Planning Board, 1990, quoted in Chang, Ch'an-sŏp, \& Chang, Nahn-joo, The Korean management system: Cultural, political, economic foundations, Greenwood Publishing Group and Quorum Books, 1994.

${ }^{35}$ Male Only, 1990, quoted in Chang, Ch'an-sŏp, \& Chang, Nahn-joo, The Korean management system: Cultural, political, economic foundations, Greenwood Publishing Group and Quorum Books, 1994.

${ }^{36}$ Chang, Ch'an-sŏp, \& Chang, Nahn-joo, The Korean management system: Cultural, political, economic foundations, Greenwood Publishing Group and Quorum Books, 1994; Mercer LLC, 'Women's leadership development survey,' Europe Survey Report, 2011; Orr, J.E., Bohannon, A., Coleman, G., Hazucha, J., Hazard, P., Hires, T., Landis, D., Lewis, J., Provo, J., Slan-Jerusalim, R., \& Tang, King-yii, 'Talent management best
} 
Vol. 9, No. 1, 2020. pp. 61-74.

doi.org/10.22452/IJEAS.vol9no1.5

hierarchical corporate structure which offered fewer opportunities for promotion for women. This was possible due to two factors which were that there was no transparency in recruitment and the empowerment of neo-Confucian ethics that privileges male workers. ${ }^{37}$

Gender inequality in the country has had disproportionate adverse impacts on women since the 1997-1998 Asian Financial Crisis. ${ }^{38}$ Social unrests during President Moo-Hyun Roh (2003-2008) ${ }^{39}$ led him to establish the civil service commission under the president which aimed at preventing favouritism in employment ${ }^{40}$, and later the outfit was absorbed into the Ministry of Security and Public Administration. ${ }^{41}$ In essence, this was the case for those highranking public officials (i.e., the Ministry of Security and Public Administration; Ministry of Foreign Affairs and Trade), who were (as of 2006) assessed first to satisfy certain competency standards. They are evaluated at assessment centres based on certain Guidelines ${ }^{42}$. These assessments were benchmarked against similar programmes in other countries (i.e., Canada). This boosted economic growth and reduced nepotism and bias ${ }^{43}$. The trained assessor panels comprised current or former government officials with relevant experience; professors with expertise in psychology, management, and public administration; and organisational consultants (industrial and organisational psychologists). The response to such changes was controversial. ${ }^{44}$ Surveys of the assessment centre programmes showed mixed reactions. Approximately half of them indicated that the new policy was a positive and fair way to promote individuals. Simultaneously, one witnessed a dramatic social change that was easily spread or diffused from one person to another: similar policies and assessment centre programmes were adopted by other government agencies (i.e., Korean Customs Service, Korea Intellectual Property Office, City of Seoul), as well as public enterprises (i.e., the Korea Railroad Corporation) in order to drive effective and fair talent management decisions. This might be considered as a new role for the government (as opposed to the corporate domain) to

practice series: Women in leadership,' Korn/Ferry International, 2013; Renshaw, J.R., \& Lee, Joo-hee, 'Korea's unrecognized corporate scandal: The absence of women managers,' Japan Policy Research Institute Working Paper, Vol. 104, 2005; Renshaw, J.R., \& Lee, Joo-hee, 'Korea's unrecognized corporate scandal: The absence of women managers,' Japan Policy Research Institute Working Paper, Vol. 104, 2005; International Labor Organization (ILO), Women, gender, and work, Geneva, Switzerland: ILO Press, 2001.

Korean Data, 'Survey on economically active population,' Seoul, Korea, 2002.

${ }^{37}$ Renshaw, J.R., \& Lee, Joo-hee, 'Korea's unrecognized corporate scandal: The absence of women managers,' Japan Policy Research Institute Working Paper, Vol. 104, 2005.

${ }^{38}$ Byung, Cheon, Chang, You, Hwang, Ji-yeun, Shin, Gyu-seong, Kang, Jin-wook, Lee, Shin-wook, Kim, Byung-hee, \& Hyun Joo, 'Growing inequality and its impacts in Korea,' GINI, Country Report for Korea, 2013.

Miller, L., The professional struggles of contemporary Korean women: Origins and consequences of the glass ceiling, Doctoral Dissertation, The University of San Francisco, 2011.

${ }^{39}$ Despite the absence of rigid class Chang, Ch'an-sŏp, \& Chang, Nahn-joo, The Korean management system: Cultural, political, economic foundations, Greenwood Publishing Group and Quorum Books, 1994; Mercer LLC, 'Women's leadership development survey,' Europe Survey Report, 2011; Orr, J.E., Bohannon, A., Coleman, G., Hazucha, J., Hazard, P., Hires, T., Landis, D., Lewis, J., Provo, J., Slan-Jerusalim, R., \& Tang, King-yii, 'Talent management best practice series: Women in leadership,' Korn/Ferry International, 2013; Renshaw, J.R., \& Lee, Joo-hee, 'Korea's unrecognized corporate scandal: The absence of women managers,' Japan Policy Research Institute Working Paper, Vol. 104, 2005.

${ }^{40}$ In fact, Park Chung-hee administration adopted a Japanese model of governance reflecting a corporate state old boy's network which did draw on the protectionist Confucian values.

${ }^{41}$ Keun, Nam-koong, 'Civil service reform in participatory government: Civil service system in transition,' The Korean Journal of Policy Studies, Vol. 22(1), pp: 19-45, 2007.

${ }^{42}$ International Task Force, 2009, quoted in

Thornton III, G.C., Rupp, D.E., \& Hoffman, B.J., Assessment center perspectives for talent management strategies, Routledge, (2 $2^{\text {nd }}$ Eds. $), 2015$.

43 Thornton III, G.C., Rupp, D.E., \& Hoffman, B.J., Assessment center perspectives for talent management strategies, Routledge, ( $2^{\text {nd }}$ Eds. $), 2015$.

${ }^{44}$ Thornton III, G.C., Rupp, D.E., \& Hoffman, B.J., Assessment center perspectives for talent management strategies, Routledge, (2 ${ }^{\text {nd }}$ Eds.) 2015. 
Vol. 9, No. 1, 2020. pp. 61-74.

doi.org/10.22452/IJEAS.vol9no1.5

lead progressive change. ${ }^{45}$ Eventually, the assessment centre method as part of a strategic initiative was embraced by the South Korean government. ${ }^{46}$ In 2010 , the percentage of female government employees at the federal government level was 41 per cent; however, it was apparent that this share was below the parity level of 50 per cent ${ }^{47}$ and that the inequality is evident in the government sector as well. Although the issue of gender gap ${ }^{48}$ in government was addressed by the Moon Jae-in administration (10 ${ }^{\text {th }}$ May 2017-incumbent), it merely set modest goals whereby women would make up 10 per cent of senior government positions and 20 per cent of company executives by $2022 .{ }^{49}$

Table 2: Employment/population ration by age group (15-64) and sex (percentage) ${ }^{50}$

\begin{tabular}{|c|c|c|c|c|c|c|c|c|c|c|}
\hline Year/Gender & 1990 & 1995 & 2000 & 2005 & 2010 & 2015 & 2016 & 2017 & 2018 & 2019 \\
\hline Women & 46.1 & 47.6 & 47.0 & 48.6 & 47.9 & 50.1 & 50.3 & 50.8 & 50.9 & 51.6 \\
\hline Men & 71.9 & 74.6 & 70.8 & 71.9 & 70.3 & 71.4 & 71.2 & 71.2 & 70.8 & 70.6 \\
\hline
\end{tabular}

Source: OECD (2020)

In terms of government and private sector organisations, the labour force participation rate for women and men in South Korea was 71 per cent and 52 per cent respectively in 2019. Male participation was largely stable, though their numbers have fallen. On the other hand, there has been a steady increase in the participation rate of women especially over the past decade, and it is expected to grow over the coming years. ${ }^{51}$ According to statistics from 2010 to 2020, 4.77 per cent of the people were actively employed in the agricultural sector, 25.01 per cent in manufacturing while the rest in the services sector. ${ }^{52}$ Based on these, it is safe to assume that South Korea is still at a snail's pace with regards to gender equality in talent management. ${ }^{53}$

\footnotetext{
${ }^{45}$ Thornton III, G.C., Rupp, D.E., \& Hoffman, B.J., Assessment center perspectives for talent management strategies, Routledge, (2 ${ }^{\text {nd }}$ Eds.), 2015

${ }^{46}$ Thornton III, G.C., Rupp, D.E., \& Hoffman, B.J., Assessment center perspectives for talent management strategies, Routledge, (2 $2^{\text {nd }}$ Eds.) 2015.

${ }^{47}$ Kim, Jin-young, Lee, Jong-wha, \& Shin, Kwan-ho, 'Impact of gender inequality on the Republic of Korea's long-term economic growth: An application of the theoretical model of gender inequality and economic growth,' ADB Economics Working Paper Series, Vol. 473, 2016.

${ }^{48}$ In general, there is a pronounced gender gap in monthly salaries for South Korean employees across all occupation types. In 2019, male managers earned on average around 8.73 million South Korean won per month, while their female counterparts earned approximately 7.27 million South Korean won. (Yoon, Jang-seob, 2020) Yoon, Jang-seob, 'Gender pay gap South Korea 2019,' Statista, 2020

${ }^{49}$ Stangarone, T., 'Gender inequality makes South Korea poorer,' The Diplomat, 2019.

${ }^{50}$ Organization for Economic Co-operation and Development (OECD), 'Employment: Employment/population ratio, by sex and age group,' OECD, 2020.

${ }^{51}$ Won, So., 'Employment to population ratio South Korea 2000-2019 by gender,' Statista, 2020

52Plecher, H., 'Employment by economic sector in South Korea 2020,' Statista, 2020. Lee, Jung-min, 'The labor market in South Korea, 2000-2018,' IZA World of Labor, 2017(2020).

${ }^{53}$ Yurdagul, E., 'An economic approach to the Segyehwa: The way of Koreanization process and the chaebŏl,' The International Association of Academicians and Researchers (INAAR), 2014b.

Yurdagul, E., 'The impacts of corruption on the South Korean economic growth: The case of South Korean chaebŏls,' The International Journal of Arts \& Sciences (IJAS), 2014c; Yurdagul, E., 'Korean innovation trends and its weakness: The chaebŏl as an obstacle to economy,' Macau, China: International Interdisciplinary Conference, 2014d; Yurdagul, E., Multinational conglomerates of the Korean economic miracle on the Han River in the European Union: The case of the South Korean chaebŏls in Germany, Doctoral Dissertation, Frankfurt am Main, Germany: Johann-Wolfgang-Goethe University, 2015; Yurdagul, E., International human resource management: The South Korean human resource management from the past to the present into the future, Ahmedabad, India: Sara Publication, 2019.
} 


\section{CONCLUSION}

Strong talent-management will be the key to gain benefits from human capital. In order to remain competitive in this changing environment, the South Korean government must legally ensure gender diversity, inclusion, and empowerment in talent management by enforcing laws and regulations that require fair and equal treatment for South Korean women and maximising their economic, social, and environmental roles in organisations. The lack of gender diversity, inclusion, and empowerment in the workplace may be attributed to conscious/explicit or unconscious/implicit bias of Koreans who discrimination (behavioural bias) explicitly or implicitly unconscious gender bias in government and private sector organisations. ${ }^{54}$ For many government and private sector organisations, the journey towards gender equality through diversity, inclusion, and empowerment is an evolving process. ${ }^{55}$ Specifically, in Korea, the journey towards gender equality involves deepening an understanding of gender equality through diversity, inclusion, and empowerment; and the utilisation of female talent. ${ }^{56}$ Both government and private sector organisations must adapt their policies, practices and culture to the changing profile of the workforce there needs a good solution to remove roadblocks by changing attitudinal norms in the Korean business environment and society. This will minimise talent loss of women in the workplaceand ensuring balance in workforce and family, as well as provide a better solution to the ageing workforce. In the long run result it will result in a creative economy, ensure greater transparency in corporate governance practices. South Korea is facing two domestic problems which is declining birth rate and an ageing society. Not encouraging women to get involved more in the workforce will eventually create severe labour shortages in the country. South Korea's Ministry of Gender Equality and Family has to devise a better plan to incorporate women into the workforce. For example, better policy interventions such as affordable childcare services would-be a boost for working mothers. Though there is an increase in women's education level, lack of gender equality has put forth barriers to women's labour force participation in Korea and this in the long run will have a profound effect on the country's economic growth.

\footnotetext{
${ }^{54}$ Begeny, C.T., Ryan, M.K., Moss-Racusin, C.A., \& Ravetz, G., 'In some professions, women have become well represented, yet gender bias persists-Perpetuated by those who think it is not happening,' Sci Adv, Vol. 6, 2020. Cherry, K., 'How people's prejudices develop,' Verywellmind, 2020a.

Cherry, K., 'How does implicit bias influence behavior?' Verywellmind, 2020b.

Fiske, S.T., 'Prejudice, discrimination, and stereotyping,' In R., Biswas-Diener, \& E., Diener (Eds.), Noba textbook series: Psychology, DEF publishers, 2021.

International Labor Office (ILO), Gender diversity journey company good practices, Bureau for Employers' Activities (ACT/EMP): ILO Press, 2017.

Mind Tools Content Team, 'Avoiding unconscious bias at work: Avoiding accidental discrimination,' Mindtools, 2018.

National Center for Cultural Competence (NCCC), 'Conscious \& unconscious biases in health care,' NCCC, 2021.

${ }^{55}$ International Labor Office (ILO), Gender diversity journey company good practices, Bureau for Employers' Activities (ACT/EMP): ILO Press, 2017.

${ }^{56}$ International Labor Office (ILO), Gender diversity journey company good practices, Bureau for Employers' Activities (ACT/EMP): ILO Press, 2017.

Afrin, S. 'Talent management and utilisation of female talent,' Stream 06 Human Resource Management Refereed Delivered Session, 2016.
} 


\section{REFERENCES}

Abasi, E., Tafazzoli, M., Esmaily, H., \& Hasanabadi, H., 'The effect of maternal-fetal attachment education on maternal mental health,' Turk J Med Sci, Vol. 43, 815-820, 2013.

Afrin, S. 'Talent management and utilisation of female talent,' Stream 06 Human Resource Management Refereed Delivered Session, 2016.

Ahern, K.R., \& Dittmar, A.K., 'The changing of the boards: The impact on firm valuation of mandated female board representation,' Working paper, 2011.

Al Aina, R., \& Atan, T., 'The impact of implementing talent management practices on sustainable organizational performance,' Sustainability, 2020.

An, R., Meng, J., \& Zhang, X., 'Analysis and experience reference of science and technology talent development strategy in developed countries,' Advances in Social Science, Education and Humanities Research, Vol. 72, 2017.

Ansar, N., \& Baloch, A., 'Talent and talent management: Definition and issues,' IBT Journal of Business Studies Volume, 14(2), 213-230, 2018.

Begeny, C.T., Ryan, M.K., Moss-Racusin, C.A., \& Ravetz, G., 'In some professions, women have become well represented, yet gender bias persists-Perpetuated by those who think it is not happening,' Sci Adv, Vol. 6, 2020.

Bersin, J., 'Talent management What is it? Why now?' Hay Acquisition Company, 2006.

Byung, Cheon, Chang, You, Hwang, Ji-yeun, Shin, Gyu-seong, Kang, Jin-wook, Lee, Shinwook, Kim, Byung-hee, \& Hyun Joo, 'Growing inequality and its impacts in Korea,' GINI, Country Report for Korea, 2013.

Cappelli, P., Talent on demand: Managing talent in an age of uncertainty, Harvard Business School Press, 2008.

Carpenter, M., Bauer, T., \& Erdogan, B., 'Management and organizational behavior (Version 1.1.1),' Flatworld Knowledge, Vol. 409, 2013.

Catalyst, 'The bottom line: Connecting corporate performance and gender diversity,' Catalyst, 2004.

Catalyst, 'The bottom line: Corporate performance and women's representation on boards,' Catalyst, 2007.

Catalyst, 'The bottom line: Corporate performance and women's representation on Boards (2004-2008),' Catalyst, 2011 a.

Catalyst, 'Gender and corporate social responsibility: It's a matter of sustainability,' Catalyst, 2011b.

Chambers, E., Foulon, M., Handfield-Jones, H., Hankin, S., \& Michaels III, E., 'The war for talent,' The McKinsey Quarterly, Vol. 3, pp: 44-57, 1998. 
Chang, Ch'an-sŏp, \& Chang, Nahn-joo, The Korean management system: Cultural, political, economic foundations, Greenwood Publishing Group and Quorum Books, 1994.

Cherry, K., 'How people's prejudices develop,' Verywellmind, 2020a.

Cherry, K., 'How does implicit bias influence behavior?' Verywellmind, 2020b.

Choi, Hyae-weol, An international scientific community: Asian scholars in the United States, Praeger, 1995.

Christensen-Hughes, J., \& Rog, E., 'Talent management: A strategy for improving employee recruitment, retention and engagement within hospitality organizations,' International Journal of Contemporary Hospitality Management, Vol. 20(7), 743-757, 2008.

Collings, D., 'Toward mature talent management: Beyond shareholder value,' Human Resource Development Quarterly, Vol. 25(3), 301-319, 2014.

Cornerstoneondemand, 'Talent management 2020: Future perspectives and scenarios,' Cornerstoneondemand, 2020.

Devine, M., \& Powell, M., 'Talent management in the public sector,' The Ashridge Journal, 2008.

Dezső, C.L., \& Ross, D., 'Does female representation in top management improve firm performance? A panel data investigation,' Strategic Management Journal, 2011.

Dimitrov, K., 'Talent management-An etymological study,' Vanguard Scientific Instruments in Management, Vol. 11(2), 2015.

Dooher, M. J., \& Marting, E., 'Selection of management personnel, Volume 1,' American Management Association, 1957.

Ernst \& Young, 'Women, the next emerging market,' Ernst \& Young, Vol. 8, 2013.

Fatol, D., Robescu, D., Farkas, Z., \& Draghici, A., 'Talent management-present and future,' Online Conference on Expanding Horizons Business, Management and Technology for Better Society, 2020.

Felix, C., \& Manuel, J., 'Talent management through the management fashion lens,' 2016.

Fiske, S.T., 'Prejudice, discrimination, and stereotyping,' In R., Biswas-Diener, \& E., Diener (Eds.), Noba textbook series: Psychology, DEF publishers, 2021.

Ghosh, P., 'What is talent management? Definition, strategy, process and models,' $H R$ Technologist, 2019.

Galarza, D., \& Wickenberg, J., 'The mechanistic and political frames of talent management processes: The case of a talent analytics system,' Chalmers University of Technology, 2011.

Google, 'Talent management (About 749.000.000 Results),' Google, February 032021. 
Groves, K.S., 'Integrating leadership development and succession planning best practices,' Journal of Management Development, Vol. 26(3), pp: 239-260, 2005.

Guthridge, M., \& Komm, A.B., 'Why multinationals struggle to manage talent,' The McKinsey Quarterly, pp: 01-05, 2008.

Hariyanto, B., \& Said, L.R., 'Evaluating talent management practices,' Systematic Reviews in Pharmacy, Vol. 11(3), 640-650, 2020.

Heathfield, S.M., 'Why talent management is an important business strategy to develop,' Thebalancecareers, 2019.

https://encyclopedia.thefreedictionary.com/talent+management

Iles, P., Preece, D., \& Chuai, X., 'Talent management as a management fashion in HRD: Towards a research agenda,' Human Resource Development International, Vol., 13(2), 124$145,2010$.

International Labor Organization (ILO), Women, gender, and work, Geneva, Switzerland: ILO Press, 2001.

International Labor Office (ILO), Gender diversity journey company good practices, Bureau for Employers' Activities (ACT/EMP): ILO Press, 2017.

Jamal, H., 'Types of business organizations,' Aboutcivil, 2017.

Jacobs, D., 'Women in the pipeline: Next practice actions, The Organization, November/December 2010,' Iveybusinessjournal, 2010.

Keun, Nam-koong, 'Civil service reform in participatory government: Civil service system in transition,’'The Korean Journal of Policy Studies, Vol. 22(1), pp: 19-45, 2007.

Kim, Jin-young, Lee, Jong-wha, \& Shin, Kwan-ho, 'Impact of gender inequality on the Republic of Korea's long-term economic growth: An application of the theoretical model of gender inequality and economic growth,' ADB Economics Working Paper Series, Vol. 473, 2016.

Korean Data, ‘Survey on economically active population,' Seoul, Korea, 2002.

Lee, Jung-min, 'The labor market in South Korea, 2000-2018,' IZA World of Labor, 2017 (2020).

Luna-Arocas, R., \& Lara, F.J., 'Talent management, affective organizational commitment and service performance in local government,' Int J Environ Res Public Health, Vol. 17, 4827, 2020.

Matsa, D.A., \& Miller, A.R., 'A female style in corporate leadership? Evidence from quotas,' Working paper, 2013.

Ma“kela“, K., Bjo“rkman, I., \& Ehrnrooth, M., 'How do MNCs establish their talent pools? Influences on individuals' likelihood of being labeled as talent,' Journal of World Business, Vol. 45, 134-142, 2010. 
McKinsey \& Company, 'Women matter: Gender diversity, a corporate performance driver,' McKinsey \& Company, 2007.

McKinsey Quarterly, 'The war for talent,' McKinsey Quarterly, 1998.

Mercer LLC, ‘Women's leadership development survey,' Europe Survey Report, 2011.

Michaels, E., Handfield-Jones, H., \& Axelrod, B., The war for talent, Harvard Business Press, 2001.

Milikić, B.B., 'Promoting gender-responsive talent management in police organizations through strategic HRM measuring,' Strategic Management, Vol. 24(1), 19-29, 2019.

Miller, L., The professional struggles of contemporary Korean women: Origins and consequences of the glass ceiling, Doctoral Dissertation, The University of San Francisco, 2011.

Mills, L., Developing executive talent: A practical guide, 1976.

Minbaeva, D., \& Collings, D.G., 'Seven myths of global talent management,' International Journal of Human Resource Management, Vol. 24(9), 1762-1776, 2013.

Mind Tools Content Team, 'Avoiding unconscious bias at work: Avoiding accidental discrimination,' Mindtools, 2018.

Momtazian, M., 'What is talent management and why is it important?' Expert360, 2020.

National Center for Cultural Competence (NCCC), 'Conscious \& unconscious biases in health care,' NCCC, 2021.

Nilsson, S., \& Ellstrom, P.E., 'Employability and talent management: Challenges for HRD practices,' European Journal of Training and Development, Vol. 36(1), 26-45, 2012.

Olsen, E.A., Korea, The Divided Nation, Praeger Security International, 2005.

Organization for Economic Co-operation and Development (OECD), 'Employment: Employment/population ratio, by sex and age group,' OECD, 2020.

Orr, J.E., Bohannon, A., Coleman, G., Hazucha, J., Hazard, P., Hires, T., Landis, D., Lewis, J., Provo, J., Slan-Jerusalim, R., \& Tang, King-yii, 'Talent management best practice series: Women in leadership,' Korn/Ferry International, 2013.

Pa'wan, F., \& Said, I., 'Strengthening talent management in enhancing organizational commitment in developing countries,' Revista Argentina de Clínica Psicológica, Vol. 24(4), 67-79, 2020.

Plecher, H., 'Employment by economic sector in South Korea 2020,' Statista, 2020.

PricewaterhouseCoopers, 'Winning the fight for female talent: How to gain the diversity edge through inclusive recruitment,' PricewaterhouseCoopers, 2017. 
Project Management Institute, 'The competitive advantage of effective organizational talent management,' Project Management Institute, 2013.

Reihl, K.M., Hurley, R.A., \& Taber, K.H., 'Neurobiology of implicit and explicit bias: Implications for clinicians,' J Neuropsychiatry Clin Neurosci, Vol. 27(4), 2015.

Renshaw, J.R., \& Lee, Joo-hee, 'Korea's unrecognized corporate scandal: The absence of women managers,' Japan Policy Research Institute Working Paper, Vol. 104, 2005.

Ringo, T., Schweyer, A., DeMarco, M., Jones, R., \& Lesser, E., 'Integrated talent management-Turning talent management into a competitive advantage-An industry view,' IBM Global Business Services, 2010.

Ritterbush, P.C., Talent waste: How institutions of learning misdirect human resources, Acropolis Books, 1972.

Schein, E., 'Increasing organizational effectiveness through better human resources planning and development,'Sloan Management Review, Vol. 19(1), 01, 1997.

Scullion, H., \& Collings, D.G., 'Global talent management,' Journal of World Business, Vol. 45, 105-108, 2010.

Sheehan, M., \& Anderson, V., 'Talent management and organizational diversity: A call for research,' Human Resource Development Quarterly, Vol. 26(4), 2015.

Stangarone, T., 'Gender inequality makes South Korea poorer,' The Diplomat, 2019.

Thornton III, G.C., Rupp, D.E., \& Hoffman, B.J., Assessment center perspectives for talent management strategies, Routledge, $\left(2^{\text {nd }}\right.$ Eds. $),(2015)$.

Thunnissen, M., \& Buttiens, D., 'Talent management in public sector organizations: A study on the impact of contextual factors on the TM approach in Flemish and Dutch public sector organizations,' Public Personnel Management, 01-28, 2017.

Whelan, E., \& Carcary, M., 'Integrating a talent management approach to knowledge management: Are there benefits to be had?' $\operatorname{SSRN}, 2010$.

Wolfers, J., 'Diagnosing discrimination: Stock returns and CEO gender,' Journal of the European Economic Association, Vol. 4(2/3), 531-541, 2006.

Wolor, C.W., Khairunnisa, H., \& Purwana, D., 'Implementation talent management to improve organization's performance in Indonesia: To fight industrial revolution 4.0.,' International Journal of Scientific \& Technology Research, Vol. 9(2), 2020.

Won, So., 'Employment to population ratio South Korea 2000-2019 by gender,' Statista, 2020 .

Woolley, A., Chabris, C., Pentland, A., Hashmi, N., \& Malone, T., 'Evidence for a collective intelligence factor in the performance of human groups,' Science, Vol. 330(2004), 686-688, 2010. 
Yoon, Jang-seob, 'Gender pay gap South Korea 2019,' Statista, 2020.

Yurdagul, E., 'Disruptive innovation: Relationship between the advent of mobile virtual network operators (MVNO) and Korean chaebŏl,' The International Association of Academicians and Researchers (INAAR), 2013.

Yurdagul, E., 'South Korean corporate social responsibility: The case of POSCO,' Bharati Vidyapeeth Deemed University, 2014a.

Yurdagul, E., 'An economic approach to the Segyehwa: The way of Koreanization process and the chaebŏl,' The International Association of Academicians and Researchers (INAAR), $2014 b$.

Yurdagul, E., 'The impacts of corruption on the South Korean economic growth: The case of South Korean chaebŏls,' The International Journal of Arts \& Sciences (IJAS), 2014c.

Yurdagul, E., 'Korean innovation trends and its weakness: The chaebŏl as an obstacle to economy,' Macau, China: International Interdisciplinary Conference, 2014d.

Yurdagul, E., Multinational conglomerates of the Korean economic miracle on the Han River in the European Union: The case of the South Korean chaebols in Germany, Doctoral Dissertation, Frankfurt am Main, Germany: Johann-Wolfgang-Goethe University, 2015.

Yurdagul, E., International human resource management: The South Korean human resource management from the past to the present into the future, Ahmedabad, India: Sara Publication, 2019.

Zesik, B., Exploring the social and political aspects of talent management in organizations, Doctoral Dissertation, Faculty of Arts and Social Sciences, 2015. 